\title{
DJELOVANJE USTAVNIH PRAVA U GRAĐANSKOM PRAVU U PRAKSI SLOVENSKOG USTAVNOG SUDA
}

\author{
UDK: $342.56: 347(497.4)$ \\ Primljeno: veljača 2017. \\ Izvorni znanstveni rad
}

Autor u članku raspravlja o teoretskim idejama te o sudskoj i prije svega ustavnosudskoj praksi u Sloveniji u pogledu djelovanja ustavnih prava u privatnopravnim odnosima. Pravni teoretičari u Sloveniji u svojim su raspravama o utjecaju ustavnih prava na privatno pravo u Sloveniji pretežno slijedili njemačku ustavnopravnu teoriju koja pravi razliku između posrednog i neposrednog horizontalnog djelovanja ustavnih prava u građanskom pravu (direkte/indirekte Drittwirkung). U slovensko pravo je, također, uvedena doktrina o pozitivnim obvezama države, koju u slovenskom pravnom sistemu izvodimo iz članka 5. Ustava Republike Slovenije iz kojega proizlazi dužnost sve tri grane vlasti (zakonodavne, izvršne i sudske) da na teritoriju Slovenije na aktivan način osiguraju poštovanje odnosno realizaciju ustavnih prava. Autor predstavlja temeljne odluke Ustavnog suda Republike Slovenije, u kojima je Ustavni sud priznao utjecaj ustavnih prava i na građansko pravo (u civilnopravnim odnosima).

Ključne riječi: Ustavni sud, Republika Slovenija, horizontalno djelovanje ustavnih prava, građansko pravo, pozitivne obveze države

\section{UVOD U RASPRAVU}

Teorija ustavnog i građanskog prava u velikoj se mjeri bavi diskusijom o odnosu između ustavnog i građanskog prava, tj. drugim riječima, o tzv. horizontalnom djelovanju ustavnih prava (tzv. Drittwirkung ili također Horizontalwirkung) ${ }^{1}$ i različitim pogledima na ovu problematiku. ${ }^{2} \mathrm{U}$ principu, radi se o pitanju imaju li ustavna prava određeno značenje samo u odnosu između države i državljanina, odnosno radi li se o tzv. pravima usmjerenima protiv države, tj. o pravima negativnog statusa (također obrambenim pravima), ${ }^{3}$ ili pak ustavna prava djeluju

1 Engl. također horizontal effect, third party applicability.

2 Pojam Drittwirkung, prema mišljenju Krivica, danas je postao već dio europske pravne kulture. Međutim, nailazimo na njega i u engleskim, francuskim i drugim pravnim tekstovima. Matevž Krivic, „Ustavno sodišče, pristojnosti in postopek“, u.: Marjan Pavčnik/ Arne Mavčič (ur.), Ustavno sodstvo, Cankarjeva založba, Ljubljana, 2000., str. 68.

3 Nekada je važilo da se kao "prava" shvaćaju ona prava čije uređivanje je, prema društvenom ugovoru, preuzela država, međutim "slobode" bi trebale unaprijed postojati na onim područjima koja 
Dr. sc. Boštjan Tratar: Djelovanje ustavnih prava u građanskom pravu u praksi slovenskog ustavnog... Zbornik radova Pravnog fakulteta u Splitu, god. 54, 4/2017., str. 825.- 836.

također i između samih državljana, odnosno između privatnopravnih subjekata, tj. u horizontalnim pravnim odnosima. Radi se, dakle, o pitanju adresata ustavnih prava, pri čemu moramo odgovoriti na pitanje tko je sve dužan poštovati odnosno priznavati ustavna prava. Odgovor na ovo pitanje nije više kontroverzan. Danas u pravilu u ustavnoj teoriji nije sporno da ustavna prava moraju poštovati sve tzv. javnopravne osobe (država, lokalne zajednice itd.). Ali, iz povijesnog kuta, u početku se radilo o težnji da se privatno područje obrani od prekomjernih intervencija državne vlasti. Posebno u ustavnoj monarhiji time je uspostavljena neka pravna pregrada prema svemogućoj upravi, koja je bila inače podređena monarhu. ${ }^{4} \mathrm{U}$ to vrijeme, dakle, djelovanje ustavnih prava nije bilo povezano s područjem privatnopravnih odnosa. ${ }^{5}$

Međutim, rasprava o djelovanju ustavnih prava među privatnopravnim subjektima pojavila se kasnije u vremenu kada nije bilo moguće previdjeti činjenice da pored države postoje i druge socijalne snage, koje nastupaju protiv pojedinca stvarnom snagom. ${ }^{6}$ Da bi ustavna prava štitila elementarne slobode, potrebno je uspostaviti njihovo djelovanje i u odnosu prema jačim društvenim, tj. nedržavnim snagama, nedržavnim organima, privatnopravnim subjektima. ${ }^{7}$ Ustavna prava morala bi spriječiti, primjerice, udruženja da na radnopravnom tržištu postavljaju uvjete koji bi pojedincu zapravo oduzeli koalicijsku slobodu, pripadnicima neke grupe ili rase zatvorili puteve do bilo kojeg zanimanja ili odredili niže plaće za žene. Naime, potrebno je zaštititi načelo jednakog tretiranja na privatnopravnom području (zabrana diskriminacije). ${ }^{8}$ Razvoj spomenutih pogleda podupire također razvojni

(po nekim prirodnopravnim teorijama) ljudi ni sklapanjem društvenog ugovora nisu prenijeli na državu, nego su ih još zadržali izvan državnog uređenja kao preostali element "neposredno djelujućeg" prirodnog prava (sloboda govora, udruživanja itd.). Ali, već je odavno u pravnoj teoriji (usporedno s prevladavanjem pravnog pozitivizma nad prirodnopravnim shvaćanjima 18. stoljeća) prevladala drugačija podjela, naime podjela na tzv. prava negativnog statusa (njem. Abwehrrechte - prava protiv državnog miješanja u sferu slobode čovjekovog ponašanja) i prava tzv. pozitivnog statusa, kod kojih čovjek od države traži neko pozitivno djelovanje (njem. Teilhaberechte, Leistungsrechte, Schutzrechte, Einrichtungsgarantien itd.). Preuzeto prema M. Krivic, OBMP, medicina in pravo, Ljubljana, 2001., str. 27 i sl.

4 Vidjeti: F. Koja, Allgemeine Staatslehre, 1993., str. 340-342.

5 Vidjeti: Boštjan Tratar, Terciarno učinkovanje temeljnih pravic, Ljubljana, 1997., str. 91.

6 Dürig označuje spomenute socijalne snage kao "als ausserstaatliche Angreifer der Individualsphere"; detaljnije vidjeti u Grundrechte und Zivilrechtsprechung, (u.) Th. Maunz, Festschrift für Nawiasky, 1956., str. 183.

7 S obzirom na saznanje da kršenja ustavnih prava ne dolaze samo s državnog područja, nego također i nedržavnog, uvećava se potreba za pravnom državom. Pravna država, između ostalog, znači dužnost države da državljanima omogući unutrašnju i vanjsku sigurnost. Spomenuta dužnost proizlazi iz historijskog konteksta građanskog rata u Francuskoj i Engleskoj. Jean Bodin i Thomas Hobbes razvili su pojam (državnog) monopola vlasti, koji predstavlja konstituirajući uvjet nastanka moderne države. U pogledu na mogućnosti zloupotreba koje proizlaze iz monopola vlasti (Hobbes, država Leviatan), vlast se može u demokratskoj pravnoj državi izvoditi samo u okviru ustavno suglasnih zakona te s ograničenjima, koja znače ustavna prava u pogledu na njihovu obrambeno-pravnu dimenziju. Zbog spomenutih ograničenja dolazi do određenog odnosa napetosti, zato što je monopol vlasti istovremeno i sredstvo za omogućavanje sigurnosti državljana kao temeljnog legitimnog državnog cilja. Zaštitna dužnost države je, prema tome, jedna vrsta kompenzacije za prihvaćanje monopola vlasti ("Friedenspflicht"). Osiguranje zaštite državljana od strane države, naime, ne znači samo temelj pravne države, nego također državnu, ugovornu teoretsku podlogu ustavne države. C. Callies, Die Grundrechtliche Schutzpflicht im mehrpoligen Verfassungsrechtsverhältnis, 2006., str. 321.

8 Vidjeti: Th. Maunz, op. cit., str. 91. 
pristup države u oblikovanju reda, gospodarstva i društva od intervencionističke države do liberalne države (tzv. noćni čuvar). Iako država pri tome upotrebljava instrumente privatnog i upravnog prava, ne možemo previdjeti stvarnu nadmoć države nad državljanima, također na privrednom području. Nasuprot ove pozicije koja nije zasnovana na vlasti, dakle za poravnavanje nejednake snage te protiv ovisnosti pojedinca o državi, razvilo se djelovanje ustavnih prava među privatnopravnim subjektima (tj. u horizontalnim pravnim odnosima).

U središtu ustavnoteorijskih rasprava u vezi s ovim pitanjima sigurno je njemačka teorija koju je razvio Hans Carl Nipperdey o neposrednom djelovanju ustavnih prava, te teorija Güntera Düriga o posrednom djelovanju ustavnih prava među privatnopravnim subjektima. Prema teoriji neposrednog djelovanja, ustavna prava neposredno obvezuju privatnopravne subjekte. Ustavna prava je, u tom smislu, potrebno tretirati kao normativna pravila pravnog reda kao cjeline, iz koje neposredno proizlaze također prava privatnopravnih subjekata. Međutim, prema teoriji posrednog djelovanja ustavnih prava među privatnopravnim subjektima, ustavna prava ,zrače samo posredno, tj. putem generalnih klauzula i neodređenih pravnih pojmova privatnog prava na odnose privatnopravnih subjekata. Sadržaj ustavnog prava, dakle, u privatnom se pravu, prema spomenutoj teoriji, izražava samo kroz neposredno primjenjive odredbe iz oblasti privatnog prava. Iako su na početku, u oblasti radnog prava te na njemačkom Saveznom radnom sudu, zastupali teoriju posrednog djelovanja ustavnih prava među privatnopravnim subjektima, danas u njemačkoj ustavnoj teoriji i sudskoj praksi prevladava teorija posrednog djelovanja ustavnih prava među privatnopravnim subjektima.

Značajna u tom smislu jest odluka njemačkog Saveznog ustavnog suda u predmetu Lüth, koja je posegnula prema teoriji posrednog djelovanja ustavnih prava među privatnopravnim subjektima. Sud je u spomenutoj odluci naveo da ustavna prava nije moguće poimati samo kao obrambena prava državljanina protiv države (tj. kao prava negativnog statusa), nego također i kao objektivne ustavne vrijednosne odluke, koje treba ostvariti u cjelom pravnom redu (tj. vrijednosne smjernice). Sud je također objasnio da ustavna prava „zrače“ svoj objektivni pravni sadržaj u privatnopravnu oblast naročito kod konkretizacije generalnih klauzula privatnog prava te neodređenih pravnih pojmova. Odluka u predmetu Lüth, kojom je njemački Savezni ustavni sud priznao učinak zračenja ustavnih prava, kasnije je bila više puta potvrđena, što je rezultiralo ustaljenom sudskom praksom.

\section{POLAZIŠTA U SLOVENSKOJ PRAVNOJ TEORIJI}

Problematika djelovanja ustavnih prava među privatnopravnim subjektima u slovenskoj pravnoj teoriji detaljno nije bila obrađena. ${ }^{9}$ Međutim, u teoriji, pa tako i u sudskoj praksi, radi se pretežno o prikazima i pozivanju na njemačku pravnu

9 Tako i M. Krivic, op. cit., str. 68-69; vidjeti također M. Orehar Ivanc, Varstvo osebnostnih pravic v ustavnem in v zasebnem pravu, 2004., str. 145. 
teoriju posrednog Drittwirkunga. Među prvima je o spomenutoj problematici pisao Krivic, koji se oslanjao na onaj dio njemačke ustavnopravne teorije koji pravi razliku među posrednim i neposrednim djelovanjem ustavnih prava među privatnopravnim subjektima i prema kome je posredno djelovanje pravilo, a neposredno djeluju samo ona ustavna prava za koja je tako određeno u Ustavu. Pritom, Krivic ne razlikuje vezanost zakonodavca od vezanosti privatnopravnih subjekata. ${ }^{10}$

Na više mesta je također bivši ustavni sudac Šinkovec izložio pitanje vezanosti privatnih (pravnih) osoba na ustavna prava u odnosu s drugim individualnim osobama u poglavlju o adresatima ustavnih prava. Svoja stanovišta oslanja na njemačku teoriju i naglašava da ustavna prava prema smislu djeluju također među pojedincima i da su ih svi dužni poštovati. ${ }^{11}$ U komentaru uz Obligacijski zakonik, u vezi s načelom savjesnosti i poštenja (članak 5.), Šinkovec posebno naglašava: »... ovo načelo se suočava s ustavnim pravima i slobodama, jer ona djeluju neposredno. Ako smo prihvatili generalne klauzule civilnog prava kao dio ustavnog reda, onda je zaključak razumljiv. Ustavna prava i slobode djeluju posredno također protiv trećih, što potvrđuje historijski razvoj ... $\ll^{12}$

Sajovic je u raspravi o problematici odnosa među ustavnim odredbama i civilnopravnim pravima proizlazio iz Leisnerovih stanovišta. Između ostalog, on navodi da: »... ustavne odredbe (vodila) ne smiju ograničavati pozitivni razvoj oblikovanja novih pojmovnih elemenata kod pojedine civilnopravne figure, koju ne bilo moguće neposredno izvoditi iz jednog ili drugog pravila ustava. ... U suštini, ovakav pristup znači i obogaćenje samog ustavnog poretka. «13

Nerad također povezuje pitanje djelovanja ustavnih prava u odnosu između privatnopravnih subjekata s pitanjem o adresatima ustavnih prava. On se oslonio na stanovište njemačke teorije o posrednom i neposrednom djelovanju ustavnih prava. Nerad posebno spominje stanovište njemačke ustavnosudske prakse o radijacijskom učinku (učinku zračenja) ustavnih prava i o zaštitnoj dužnosti države. $\mathrm{Na}$ osnovi spomenutih stavova zaključuje da ustavna prava imaju radijacijski efekt na zakonodavstvo iz oblasti privatnog prava. Posrednost, odnosno neposrednost djelovanja ljudskih prava prema slovenskom ustavu u privatnopravnim odnosima trebala bi, prema stavu Nerada, ovisiti o tome je li ustavna odredba neposredno ostvariva ili ona zahtijeva zakonsko određenje načina ostvarivanja. Pojedinci bi trebali biti neposredno vezani na ona ustavna prava koja su ostvariva neposredno na osnovi Ustava. Samo iz tako opredijeljenih ustavnih prava proizlazi dovoljno određena dužnost da bi pojedinac uopće znao kako treba postupati. ${ }^{14}$ Prema stavu

10 Vidjeti: M. Krivic, op. cit., str. 68. i dalje.

11 Vidjeti opće: J. Šinkovec, Pravice in svoboščine, Založba uradni list, Ljubljana, 1997. Vidjeti također J. Sinkovec, Podjetništvo in ustavne pravice, 1994.; J. Šinkovec, Razmerja med ustavnim in civilnim pravom, 2000.

12 Vidjeti: J. Šinkovec/ B. Tratar, Obligacijski zakonik s komentarjem in sodno prakso, 2001., str. 8.

13 Vidjeti: Bogomir Sajovic, O pravici civilnega prava, 1998, str. 94.

14 Vidjeti: M. Orehar Ivanc, op. cit., 146; videti Sebastian Nerad, Učinkovanje ustavnega načela enakosti med subjekti zasebnega prava, 2002., str. 384-385. 
Orehar Ivančeve, ${ }^{15}$ nijedno od predstavljenih stanovišta ne dovodi u pitanje djelovanje ustavnih prava također i u odnosima među pojedincima, međutim nijedno od stanovišta nije se bavilo pitanjem kako (na koji način) djeluju. Teoretičari ne prave razliku između načina djelovanja ustavnih prava na zakonodavstvo iz oblasti privatnog prava i na privatnopravne odnose. Jedini koji ukazuje na ovu razliku jest Nerad, mada ni on ne objašnjava zašto uopće postoji razlika s jedne strane između vezanosti zakonodavca u oblasti privatnog prava i u drugim oblastima te $\mathrm{s}$ druge strane između načina djelovanja ustavnih prava na zakonodavca i u odnosima između pojedinaca. Primjenjivost merila što ih on postavlja za razlikovanje među ustavnim pravima koja u odnosima među pojedincima djeluju neposredno, i onima koja djeluju posredno, jest najmanje pod upitnikom. Pojmu „neposredna ostvarivost" ustavnog prava na osnovi Ustava on očigledno daje drugačije značenje od onog koje postoji u ustavnopravnoj doktrini. Međutim, on ne navodi ni kakvi su kriteriji za odluku ni je li ustavna odredba neposredno ostvariva (u odnosima među pojedincima) ili nije. ${ }^{16}$

\section{IDEJE POZITIVNIH OBVEZA U SLOVENSKOM PRAVU}

Doktrinu pozitivnih obveza države, na osnovi Europske konvencije o ljudskim pravima, u slovenskoj teoriji predstavio je Teršse. ${ }^{17}$ Teršek navodi da Ustav Slovenije, primjerice u članku 5., određuje neke od pozitivnih obveza države (sudske, zakonodavne i izvršne grane vlasti), a na prvom mjestu spominje zaštitu ljudskih prava i temeljnih sloboda: »Država na svojem teritoriju štiti ljudska prava i temeljne slobode." Pozitivnu obvezu države u odnosu na zaštitu ljudskih prava i sloboda izvodi već iz III. člana Temeljne ustavne povelje o samostalnosti i nezavisnosti Republike Slovenije: »Republika Slovenija osigurava zaštitu ljudskih prava i temeljnih sloboda svim osobama na teritoriju Republike Slovenije, bez obzira na njihovu nacionalnu pripadnost, bez ikakve diskriminacije, i u suglasnosti s Ustavom Republike Slovenije is važećim međunarodnim ugovorima. ${ }^{18} \ldots \mathrm{Uz}$ činjenicu da slovenski Ustavni sud mora uzeti u obzir i strasburšku doktrinu o pozitivnim obvezama države, može razviti i svoju vlastitu doktrinu o pozitivnim obvezama države u vezi s ustavnim „ljudskim pravima i temeljnim slobodama“. ${ }^{19}$

Doktrinu pozitivnih obveza države je, uz komentar uz članak 5. Ustava Republike Slovenije, također predstavio i prof. dr. sc. Boštjan M. Zupančič, sudac Europskog suda za ljudska prava. On je naveo da Ustav u članku 5. određuje neke pozitivne obveze države, tj. 1) zaštitu ljudskih prava i temeljnih sloboda; 2) zaštitu (samo izričito određenih) manjina; 3) očuvanje prirodne i kulturne baštine te 4) ubrzavanje

15 Ibidem, str. 146.

16 Ibidem, str. 146.

17 Vidjeti: Andraž Teršek, Doktrina o „pozitivnih obveznostih države“ in (sistemska) odgovornost države za varovanje človekovih pravic in svoboščin, 2005.

18 Vidjeti: A. Teršek, op. cit., str. 54.

19 Ibidem, str. 55. 
civilizacijskog i kulturnog razvoja. Prema Zupančiču, razlika među pozitivnim i negativnim obvezama države razumno se preklapa s razlikom među radnjama (commissiones) i opuštanjima (omissiones). Kod pozitivnih obveza nije dovoljno da se država samo pasivno suzdrži od određenih kršenja. Pozitivna obveza državu obvezuje na minimum aktivnog ponašanja, primjerice kod zaštite života iz članka 2. Europske konvencije. Pojam pozitivnih obveza države je, prema njegovu stavu, novi, procesni pogled treće generacije ljudskih prava. ${ }^{20}$

Međutim, Teršek je posebno naglasio doktrinu pozitivnih obveza države kod opredjeljivanja nadležnosti zaštitnika ljudskih prava. ${ }^{21}$ Prema odredbi članka 159. Ustava i člana 1. Zakona o zaštitniku ljudskih prava, zadatak zaštitnika ljudskih prava jest ,zaštita ljudskih prava i temeljnih sloboda u odnosu prema državnim organima, organima lokalne samouprave i nosiocima javnih ovlaštenja“. Kod nadležnostih zaštitnika, radi se o tome da se ona ne rastežu na cjelokupnu aktivnost nosilaca javnih ovlaštenja, nego samo na one njihove aktivnosti koje znače izvođenje pojedinog javnog ovlaštenja. Teršek je uvjeren da je potrebno predmet zaštitnikove neformalne zaštite prava i sloboda shvatati uzimanjem u obzir spomenute doktrine. Naime, funkcija zaštitnikova nadzora obuhvaća, po njegovu stanovištu, sva područja na kojima je moguće uspostaviti odgovornost države s gledišta zaštite ljudskih prava i sloboda. Za efikasan nadzor nad radom državnih organa, posebno kad je u prvom planu razumijevanje i poštovanje ljudskih prava i temeljnih sloboda, čije su višeslojnost i dimenzije među središnjim ustavnopravnim kategorijama, potrebna je ona vrsta analitičke pronicljivosti i znanstvene nadogradnje općih logičkih prava, čiji preduvjet je prvenstveno dobro poznavanje različite ustavnopravne materije. Za efikasan i sveobuhvatan (ne samo površinski) nadzor nad državom potrebni su „sistemsko“ shvaćanje trodimenzionalnosti ljudskih prava i sloboda, tumačenje ustavnih prava u duhu ustava kao cjeline te prelijevanje ustava u pravni poredak pomoću temeljnih ustavnih načela i odredaba ustava o ljudskim pravima i slobodama. ${ }^{22}$

Vrhovni sud Republike Slovenije suočio se s problematikom djelovanja ustavnih prava među privatnopravnim subjektima kod odlučivanja o reviziji tužioca, čiji je tužbeni zahtev, kojim je tražio da tuženi mora objaviti ispravku i odgovor, prvostupanjski sud odbio. ${ }^{23}$ Vrhovni sud je u obrazloženju naveo: »... Ustavna prava štite čovjeka od posezanja države odnosno uopće javne vlasti (također općina, javnih zavoda i drugih nosilaca javnih ovlaštenja). Prema tome, postavlja se principijelno pitanje da li je uopće moguća sudska zaštita ovih prava i od kršenja od strane "trećih", dakle ne države i drugih nosioca javnih ovlaštenja, nego od strane privatnih subjekata. Nema nikakve sumnje da je moguće neposredno djelovanje ustavnih prava među privatnopravnim subjektima kod onih ustavnih

20 Vidjeti: Boštjan M. Zupančič, komentar ka 5. članku Ustave, u: L. Šturm (ur.)., Komentar Ustave Republike Slovenije, 2002., str. 112.

21 Vidjeti: A. Teršek, op. cit., str. 67.

22 Sve navedeno prema A. Teršek, op. cit., str. 68.

23 Vidjeti primjerice odluku Vrhovnog suda Slovenije br. II Ips 602/97, 19. III. 1998. i br. II Ips 38/98, 19. III. 1998. 
prava kod kojih već iz ustavnog teksta proizlazi da adresatima nisu dana samo $u$ odnosu prema javnoj vlasti (takva su prema slovenskom Ustavu bez sumnje pravo na odgovor i/ili ispravku iz člana 40. Ustava. Kod drugih ustavnih prava moguće je samo posredno djelovanje ustavnih prava, i to na način da je prava koja su dana samo u zakonsko uređenim odnosima među pojedincima (privatnopravnim osobama) (civilnopravnim, radnopravnim itd.), potrebno tumačiti u svjetlu ustavno zajamčenih prava, naročito u slučaju kada to ne osigurava (ili ne osigurava u dovoljnoj mjeri) već samo zakonsko uređenje takvih odnosa odnosno prava (, ,radiacijski efekt ustavnih prava“ na zakonsko uređena prava). Pravo na odgovor i/ili ispravku iz članka 40. Ustava, koje je uzakonjeno također u odredbama Zakona o javnim glasilima - ZJG (9. - 23. članak ZJG-a), već je prema svojoj prirodi pravo koje Ustav (i na njegovoj podlozi ZJG) daje čovjeku na raspolaganje radi zaštite njegovih prava $i$ interesa $u$ odnosu prema drugim pojedincima. Pravo na odgovor i/ili ispravak čovjek naime uopće ne može ostvariti protiv države. Ovo pravo se može ostvariti samo protiv vlasnika i odgovornog urednika javnog glasila iz članka 2. ZJG-a. Međutim, u suprutnosti s pravom na ispravak i/ili odgovor iz članka 40. Ustava ( $i$ članci 9. $i$ sl. ZJG-a) jest sloboda izražavanja iz članka 39. Ustava (kao širi pojam za slobodu govora, štampe, misli itd.) ustavno pravo koje je dano naročito nasuprot nosilaca javne vlasti koji ne smiju ovo pravo protuustavno ograničavati odnosno posezati u njega. A to znači da se među pravima iz članaka 39. $i$ 40. Ustava ne radi samo ( $i$ u prvoj liniji) o odnosu širih i užih prava. Među pravima iz članka 39. i 40. Ustava postoji više razlika. Međutim, suštinska je razlika u tome protiv koga je pravo „upereno“, odnosno tko ga smije kršiti.«

\section{PRAKSA USTAVNOG SUDA REPUBLIKE SLOVENIJE}

Ustavni sud Republike Slovenije kod presuđivanja privatnopravnih odnosa, bilo na zakonodavnom ili konkretnom nivou, u vezi s problematikom djelovanja ustavnih prava među privatnopravnim subjektima zauzima slična stanovišta kao njemački Savezni ustavni sud. ${ }^{24}$

U predmetu br. U-I-202/93 ${ }^{25}$ Ustavni sud je polazio iz stava da je načelo autonomije ugovornih stranaka utemeljeno u općoj slobodi postupanja (članak 35. Ustava) i u slobodnoj privrednoj inicijativi (članak 74. Ustava) te da su zbog toga posezanja u slobodu dopuštena samo ako su ispunjeni uvjeti za ograničenje ustavnih prava prema Ustavu. Sud je među razlozima za ograničenje naveo socijalnu

24 Tako i M. Orehar Ivanc, op. cit., str. 146.

25 Vidjeti: Uradni list RS, br. 74/94 i OdIUS III, 99. »5. Dopuštenje ograničavanja ugovorne autonomije u oblasti kamata je dakle utemeljeno javnom koristi, potrebom za osiguranje socijalne sigurnosti, radi osiguranja socijalne i ekonomske funkcije vlasništva i radi osiguranja načela da je Slovenija pravna i socijalna država. S obzirom na ove podloge za dopuštenje ograničavanja slobodne ugovorne volje, zakonodavac je mogao odrediti različita ograničenja te slobode s obzirom na različite statusnopravne karakteristike pojedinih sudionika u pravnom prometu. Posebnosti u statusnopravnim karakteristikama fizičkih i pravnih osoba znače prema tome različita činjenična stanja, koja opravdavaju također različito zakonsko uređenje granica ugovorne autonomije spomenutih vrsta osoba..." 
sigurnost ugovornih stranaka. Ona je u primjeru sklapanja ugovora među privrednim subjektima manje pogođena, nego u primjeru kada ugovor sklapaju pojedinci pa, prema spomenutome, može zakonodavac razlikovati težinu posezanja između oba primjera. U spomenutoj je odluci Ustavni sud još presuđivao je li zakonodavac odustao od svoje zaštitne dužnosti time što nije odredio najviše kamatne stope za ugovore što ih međusobno sklapaju privredni subjekti. Međutim, zakonodavac je u tom slučaju na drugi način osigurao relevantna ustavna dobra, pa je prema tome Ustavni sud odlučio da zakonodavčevo napuštanje nije u nesuglasnosti s Ustavom. ${ }^{26}$

U predmetu br. U-I-108/01 ${ }^{27}$ Ustavni je sud slijedio polazište iz ranije spomenute odluke. Osporene zakonske odredbe je u oba primjera presuđivao s vidika ustavno zaštićenog položaja osporavatelja ustavnosti tj. da se radi o posezanju u njegov zaštićeni položaj. Međutim zadatak zaštite, koji je zakonodavac ispunio odnosno htio ispuniti, Ustavni je sud uzimao u obzir kod vaganja srazmjernosti u užem smislu. $^{28}$

U predmetu br. Up-20/93 ${ }^{29}$ diskusija o načinu djelovanja ustavnih prava u privatnopravnim odnosima pokazala se kao nepotrebna. S jedne strane, već je Ustavni sud naveo da je raspravljanje bilo dano obiter dictum, međutim s druge strane su bila stanovišta Ustavnog suda o spomenutom pitanju nepotrebna i zato jer sporno činjenično stanje uopće nije bilo zaštićeno ustavnim pravom čije se kršenje tvrdilo. Odluka Ustavnog suda naime izričito zauzima stav da sloboda izražavanja nikome ne jamči prava na objavu njegovih mišljenja u određenim novinama. Prema tome, bilo je suvišno baviti se pitanjem kako djeluje ustavno pravo na civilnopravni subjekt. ${ }^{30}$ Međutim, usprkos tome, iz izvođenja Ustavnog suda u spomenutom predmetu proizlaze teorijska stanovišta koja su značajna za ovu problematiku:

»37. Teorija Drittwirkung odgovara na to pitanje na način da dopušta neposredno Drittwirkung, dakle neposredno djelovanje ustavnih prava u odnosu među pojedincima samo kod onih ustavnih prava kod kojih već iz ustavnog teksta proizlazi da adresatima nisu dana samo u odnosu prema javnoj vlasti (u njemačkom ustavu se kao takvo pravo tretira samo tzv. koalicijska sloboda među partnerima tarifnih, odnosno kolektivnih ugovora. Međutim u našom ustavu je takvih prava mnogo više, a među njima su svakako i oba prava iz članka 40. Ustava). Međutim, kod ostalih ustavnih prava moguća je samo posredna Drittwirkung na

26 Tako M. Orehar Ivanc, op. cit., str. 146-147.

27 Vidjeti: Uradni list RS, št. 102/02 in OdlUS XI, 227. »47. Ukoliko ranije spomenuti razlozi još uvijek opravdavaju nužnost zaštite najamnih odnosa fizičkih osoba koje imaju poslovne prostorije u najmu kao glavni izvor izdržavanja sebe i svoje obitelji, zakonodavac bi morao produljiti jednogodišnji otkazni rok na određeno vrijeme ako ne bi mogao dostići spomenuti cilj na drugačiji način ili s blažim posegom u ustavno pravo (primjerice s određenjem odgovarajućih dažbina za ,prazne“ poslovne prostore). Međutim, uz utemeljenje nužnosti ovakve mjere, morao bi kod određivanja duljeg otkaznog roka također uzeti u obzir njegovu srazmjernost u užem smislu riječi. Međutim, iz ranije spomenutog je evidentno da je mjera kojom je stanodavcu oduzeto pravo na otkaz najamnog odnosa nesumnjivo prekomjerna i prema tome u nesuglasnosti s člankom 33. Ustava Republike Slovenije ...«

28 Tako M. Orehar Ivanc, op. cit., str. 147.

29 Vidjeti: OdlUS VI, 181.

30 Tako M. Orehar Ivanc, op. cit., str. 147. 
način da je prava, dana u samo zakonsko uređenim odnosima među pojedincima (civilnopravnim, radnopravnim itd.), potrebno tumačiti u duhu ustavno zajamčenih prava, prije svega tada kada ono ne osigurava (ili ne osigurava u dovoljnoj mjeri) već samo zakonsko uređenje takvih odnosa odnosno prava. S tim u vezi se također govori o „radijacijskom efektu ustavnih prava“ na zakonsko uređena prava (Ausstrahlungswirkung). Ako sud kod presuđivanja spora iz takvog odnosa zakonsko uređenih prava ne bi tumačio u dovoljnoj mjeri u duhu ustavnih prava, moglo bi dakle doći do ranije spomenutog posrednog kršenja ustavnih prava i do zaštite tako kršenih ustavnih prava ustavnom žalbom ispred ustavnog suda. Tipičan primjer je primjerice spolna ili rasna diskriminacija kod zapošljavanja. Ako i gdje to izričito ne zabranjuje već odgovarajuće zakonodavstvo, oštećeni bi se trebao pozivati i na posredno kršenje ustavne zabrane takve diskriminacije, iako, barem većina država, takvu diskriminaciju ustavima izričito zabranjuje samo nosiocima javne vlasti.

38. Međutim, kao što je već spomenuto u slovenskom ustavu - u usporedbi s tradicionalnim zapadnoeuropskim ustavima - ima neobično mnogo ustavnih prava kod kojih već iz ustavnog teksta više ili manje jasno proizlazi da se radi o pravima koja ustav daje čovjeku također nasuprot ostalih pojedinaca-neka čak prije svega nasuprot njima ili se radi o primjerima da neka od tih prava protiv nosioca javnih ovlaštenja neposredno uopće nije moguće primijeniti (primjerice pravo roditelja na djecu i obrnuto). Baš pravo na odgovor iz članka 40. Ustava jest posebno tipično pravo ove vrste, koje je već prema svojoj prirodi takvo da ga čovjek uopće ne može ostvariti protiv države, nego samo protiv vlasnika i urednika novina ili RTV-postaja. Međutim, kod javnih radijskih ili televizijskih postaja, kao javnih zavoda i time nosilaca javnih ovlaštenja, situacija je drugačija. Jer je - u suprotnosti s tim sloboda izražavanja iz članka 39. Ustava (kao širi pojam za slobodu govora, štampe itd.) ustavno pravo, koje je dano prije svega protiv nosilaca javne vlasti koji ga ne smiju protuustavno ograničavati ili u njega posezati, dakle među pravima iz članka 39. $i$ 40. Ustava ne radi se samo ( $i$ u prvom redu) o odnosu šireg i užeg prava.«

U predmetu br. Up-32/94 također su bliski stavovi njemačke i slovenske ustavosudske procjene u pogledu procjene ustavnosti presuda civilnopravne vlasti. ${ }^{31}$ Ustavni sud je polazio od stava da je predmet procjene sudska odluka, a ne ponašanje pojedinca. Naveo je da posezanje u ustavno pravo ne diktiraju i ne opravdavaju ni javni poredak, ni zaštita prava drugih te objasnio da je Ustavom saglasno tumačenje moguće u okviru važećeg zakona. Ustavni sud je sudsku odluku prepoznao kao neskladnu s Ustavom zbog toga što sud kod tumačenja zakonskih odredbi, na kojima se temelji sudska odluka, nije uzeo u obzir sve ustavno relevantne stavove. ${ }^{32}$

31 Ibidem, str. 148.

32 Vidjeti: OdlUS IV, 38. 10. Iz spomenutih odredaba između ostalog proizlazi da mora imati sud u svom radu sve vrijeme pred očima također odredbe o ljudskim pravima i temeljnim slobodama. Sud svojim postupcima i odlukama ostvaruje $i$ štiti ljudska prava i temeljne slobode. U njih poseže samo tada i utoliko, koliko to određuje ili dopušta Ustav ili po njegovu ovlaštenju zakon ili Europska konvencija o ljudskim pravima. Sudski put je najefikasniji način ostvarivanja ljudskih prava i temeljnih sloboda u pojedinom slučaju. S druge strane, mogli bi sudski postupci i sudske odluke snažno posegnuti u ljudska prava zajamčena Ustavom. Ni za jedan sudski postupak nije unaprijed isključeno da ne bi mogla biti u 
Slično je Ustavni sud Slovenije u predmetu br. Up-181/9933 presudio odluku izvršnog suda, kojom je zbog zakašnjenja s ispunjenjem obveza iz sudske odluke dužniku određena naplata sudskih penala. Iz odluke proizlazi stav da zakonsko uređenje sudskih penala razrješuje koliziju između povjerenikova prava na izvršenje sudske odluke kao sastavnog dijela prava na sudsku zaštitu (članak 23. Ustava) i dužnikova prava na privatno vlasništvo (članak 33. Ustava) u granicama prostora koji Ustav dopušta zakonodavcu, i da ni sudska odluka nije previdjela nijedan ustavnorelevantni stav. Usprkos tome što nije izričito objašnjeno, ipak iz odluke jasno proizlazi stav Ustavnog suda da je institutom sudskih penala zakonodavac ispunjavao zadatak zaštite, koja proizlazi iz prava na sudsku zaštitu. ${ }^{34}$ Povjereniku daje Ustavni sud za utjerivanje duga iz pravnosnažne sudske odluke na raspolaganje dvije mogućnosti: tražiti izvršenje izvršnim sredstvima iz izvršnog postupka, ili isti cilj dosegnuti određenjem sudskih penala. U nastavku je Ustavni sud presudio da određenje sudskih penala u konkretnom primjeru nije kršilo dužnikovo pravo na privatno vlasništvo, što znači da je osporenom sudskom odlukom uspostavljena ustavno skladna ravnoteža među kolidirajućim ustavnim pravima. Iz odluke proizlazi da Ustavni sud nije presudio suglasnost sveukupnog zakonskog uređenja s Ustavom, nego (posredno) samo onaj dio koji je bio relevantan za odluku u tom predmetu. ${ }^{35}$

\section{ZAKLJUČAK}

Ustavni sud Republike Slovenije u nekoliko je svojih odluka naglasio da redovni sud kod odlučivanja u svojim predmetima sve vrijeme mora imati pred očima također i odredbe o ljudskim pravima i temeljnim slobodama, a to upravo zbog namjere da ih može osigurati odnosno zajamčiti na efektivan način u svim pravnim odnosima, pa tako i u građanskopravnim. Time je Ustavni sud Republike Slovenije na neki način prihvatio objektivno poimanje ustavnih prava, kako se ono razvilo u njemačkom pravnom sistemu, u kojemu ustavna prava predstavljaju objektivna usmjerenja za cjelokupan pravni poredak.

Ovaj zahtjev, naime, nalaže da zakonodavna, izvršna i sudska grana vlasti svim mjerama osiguravaju ustavna prava na cjelokupnom području države. Međutim, to s druge strane znači da pojedinci također moraju u međusobnim odnosima, to jest u tzv. horizontalnim pravnim odnosima poštovati ustavna jamstva. Time u suštini

njemu i njime kršena ljudska prava ili temeljne slobode. Ovo važi također za parnicu na osnovi tužbe zbog ometanja državine (posjeda). Naime, i sadržajno ograničenim i prema svojoj prirodi provizornim rješenjem, kojim se takva parnica završava i koje uređuje samo pitanja stvarne (faktičke) vlasti nad stvarima, moguće je za dulje vrijeme posegnuti u ustavno zajamčena ljudska prava i temeljne slobode što može značiti za pogođenu osobu značajnije posljedice - $i$ u tom slučaju pripada toj osobi ustavnosudska zaštita. Međutim, i odredbu članka 78. Zakona o temeljima imovinskopravnih odnosa ne možemo tumačiti tako da sud u parnici zbog ometanja posjeda ne bi mogao uzimati u obzir i ustavna prava.

33 Vidjeti: Uradni list RS, št. 7/2003 i OdlUS XI, 292.

34 Tako: M. Orehar Ivanc, op. cit., str. 148.

35 Ibidem. 
i sami privatnopravni subjekti postaju, pored države, adresati ustavnih prava, ne samo nosioci prava. Međutim, Ustavni sud Republike Slovenije je svojim odlukama uspostavio također dužnost države kao cjeline da na aktivan način, tj. putem zaštitnih dužnosti države, osigurava svestranu realizaciju ustavnih prava (u vertikalnim i u horizontalnim pravnim odnosima).

\section{LITERATURA:}

Christian Callies: „Die Grundrechtliche Schutzpflicht im mehrpoligen Verfassungsrechtsverhältnis“, u: Juristenzeitung, br. 7/2006., str. 321 i sl.

Matevž Krivic: „Ustavno sodišče, pristojnosti in postopek“, u.: Marjan Pavčnik/ Arne Mavčič (ur.), Ustavno sodstvo, Cankarjeva založba, Ljubljana, 2000.

Matevž Krivic: „OBMP, medicina in pravo “, u: Pravna praksa, br. 29/ 2001., Ljubljana.

FriedrichKoja:AllgemeineStaatslehre,ManzscheVerlags-undUniversitätsbuchhandlung, Wien, 1993.

Sebastian Nerad: „Učinkovanje ustavnega načela enakosti med subjekti zasebnega prava“, u: Javna uprava, let. 38, br. 3/2002., Inštitut za javno upravo, Ljubljana, str. 373394.

Metoda Orehar Ivanc: Varstvo osebnostnih pravic v ustavnem in $v$ zasebnem pravu, magistarski rad, Univerza u Ljubljani, Pravni fakultet, Ljubljana, 2004. 1998.

Bogomir Sajovic: O pravici civilnega prava, Časopisni zavod Uradni list, Ljubljana,

Janez Šinkovec: Pravice in svoboščine, Založba uradni list, Ljubljana, 1997.

Janez Šinkovec: Podjetništvo in ustavne pravice, 1994.

Janez Šinkovec: „Razmerja med ustavnim in civilnim pravom“, u: Podjetje in delo, let. 26., br. 6-7/2000., Ljubljana, 2000., str. 970-979.

Janez Šinkovec/ Boštjan Tratar: Obligacijski zakonik s komentarjem in sodno prakso, Založba Oziris, 2001.

Lovro Šturm (ur.): Komentar Ustave Republike Slovenije, Fakulteta za podiplomske in evropske študije, Ljubljana, 2002.

Andraž Teršek: Doktrina o "pozitivnih obveznostih države” in (sistemska) odgovornost države za varovanje človekovih pravic in svoboščin, 2005.

Boštjan Tratar: „Terciarno učinkovanje temeljnih pravic“, u: Pravosodni bilten, br. 5/1997., Ljubljana, 1997.

Boštjan Tratar: „Autonomija zakonodavne grane vlasti u svetlu dužnosti obezbeđivanja ustavnih prava“, u: Pravni život, br. 12/2005., Beograd, str. 559-576.

Predmeti - presude Ustavnog suda Republike Slovenije. 


\section{EFFECTING CONSTITUTIONAL RIGHTS IN CIVIL LAW IN JUDICATURE OF CONSTITUTIONAL COURT OF REPUBLIC OF SLOVENIA}

The author discusses teoretical ideas and judicial and constitutional judicature in the Republic of Slovenia as regards effecting constitutional rights in relations among private subjects. Slovene legal theorists have, by discusions of influence of the constitutional rights on civil law, mainly followed the German constitutional theory that makes differences between indirect and direct horizontal effect of constitutional rights in civil law (direkte/indirekte Drittwirkung). In Slovene legal system the doctrine on positive obligations of the state also put into force which is in Slovene law based upon Art. 5 of Slovene Constitution. From this provision derives the duty of all three branches of power (legislative, executive and judicial) that on the teritorry of Slovenia they activly guarantee the respect and/or realisation of the constitutional rights. The author presents the key decisions of the constitutional court of the Republic of Slovenia, in which the Constitutional Court confirmed the effects of the constitutional rights also in civil law.

Key words: Constitutional Court, Republic of Slovenia, horizontal effects of constitutional rights (third party effect), civil law, positive duties of the state 